\title{
Female Employment in the Manufacturing Sector of Industry 4.0: A SWOT Analysis
}

\author{
Ilyana Janis ${ }^{a^{*},}$ Muhammad Zulkiplib \\ ${ }^{a}$ Faculty of Technical and Vocational Education, Universiti Tun Hussein Onn Malaysia, 86400 UTHM Parit Raja, Johor, Malaysia \\ ${ }^{b}$ Faculty of Engineering Technology, Universiti Tun Hussein Onn Malaysia, 84600 Pagoh, Johor, Malaysia \\ *Corresponding author: gb180091@siswa.uthm.edu.my
}

Article history: Received: 01 January 2020 Received in revised form: 09 February 2020 Accepted: 02 March 2020 Published online: 26 August 2020

\begin{abstract}
In global context, women make up the majority of students in academic institutions but are far less involved in manufacturing academic courses and work in the manufacturing sector. There are several reasons for this. There is a general perception among women that manufacturing carries a high risk of danger. Additionally, there are some tasks in the manufacturing sector that women are often physically unable to perform, such as those in the machinery, industrial equipment and automotive sector. The arrival of Industry 4.0 technology in the manufacturing sector, however, is likely to result in a decline in physical and onerous duties - overtly physical jobs could be replaced by automation and robotics. The cognitive abilities required for the development and implementation of full automation present vast opportunities for women. This paper aims to explore the strengths, weaknesses, opportunities and threats (SWOT) presented by women employment in the Industry 4.0 manufacturing sector. Thirty pieces of literature related to women employed in the manufacturing sector are reviewed. SWOT analysis is derived from the solo-coding process using ATLAS.ti. The results are found through qualitative thematic analysis and reveal that the weaknesses of and threats posed by women employment in the manufacturing sector could be outweighed by the strengths of and opportunities provided by Industry 4.0. This SWOT analysis contributes to the literature by providing a greater understanding of women employment in the Industry 4.0 manufacturing sector.
\end{abstract}

Keywords: Industry 4.0, female employment, women employment, worldwide, Malaysia and manufacturing sector.

\section{Abstrak}

Dalam konteks globalisasi, pelajar perempuan adalah majoriti dalam institusi pendidikan tetapi kurang di dalam bidang akademik terutamanya kursus pembuatan dan bekerja di sektor pembuatan. Terdapat beberapa sebab kepada hal ini. Persepsi kebanyakan wanita bahawa bekerja di dalam sektor pembuatan adalah berisiko tinggi dan terdedah kepada segala bahaya. Tambahan pula, kerja-kerja yang terdapat di dalam sektor pembuatan adalah kerja yang melibatkan aktiviti fisikal, di mana kebiasaanya wanita tidak mampu untuk melakukan aktitviti-aktiviti berat yang melibatkan fisikal, contohnya dalam bidang pemesinan, peralatan industri dan automotif. Kehadiran teknologi Industri 4.0 di dalam sektor pembuatan, menyaksikan pengurangan keperluan yang melibatkan fisikal kerana pekerjaan yang melibatkan fisikal digantikan dengan penggunaan robotik dan automasi. Keupayaan kognitif lebih diperlukan dalam membangunkan dan melaksanakan automasi dan keperluan kognitif ini mewujudkan banyak peluang pekerjaan kepada wanita. Artikel ini bertujuan untuk meneroka kekuatan (Strength), Kelemahan (Weakness), Peluang (Opportunity) dan Ancaman (Threat) yang terdapat pada wanita untuk bekerja di dalam sektor pembuatan yang mempunyai teknologi Industri 4.0. Tiga puluh artikel berkaitan dengan wanita dan kerjaya dalam bidang pembuatan telah dikaji. SWOT analysis yang diperoleh hasil daripada proses pengekodan yang dilakukan secara solo dengan menggunakan perisian ATLAS ti. Dapatan kajian yang diperoleh daripada tematik analis ini menemui bahawa kelemahan dan cabaran yang dihadapi oleh wanita untuk bekerja di sektor pembuatan boleh di atasi dengan melihat dari sudut kekuatan dan peluang yang ditawarkan oleh Industri 4.0 teknologi. SWOT analisis ini juga menyumbang kepada literasi dalam menyediakan lebih kefahaman terhadap wanita yang mahu bekerja di dalam sektor pembuatan Industri 4.0.

Kata kunci: Industri 4.0, kerjaya wanita, global, Malaysia dan sektor pembuatan.

(C) 2020 Penerbit UTM Press. All rights reserved

\subsection{INTRODUCTION}

Historical differences in economic roles - women in domestic roles and men as family breadwinners-have led to entrenched, socially constructed gender roles (Thompson, 2004, p. 218). Since the $17^{\text {th }}$ century, however, women have been entering male-dominated professional fields. According to Domenico and Jones (2006), women in the $17^{\text {th }}$ century were generally either involved with a family business or simply stayed at home. Women participation began to grow during the Industrial Revolution, from the late $18^{\text {th }}$ to early $19^{\text {th }}$ century-women took on roles in the textile, clothing, pottery and food industries using traditionally feminine skills such as sewing, pottering and cooking (Berg, 1991). The scope of occupations for women increased drastically during the Second Industrial Revolution, as women were needed in manufacturing positions during the two world wars; they were often employed to work in artillery plants making fibre powder containers (US Department of Defense, 2017). In the late $20^{\text {th }}$ century, women were given equal rights regarding job 
opportunities in mainstream engineering (Mack, 2001). Despite this step, however, women remained a minority in the field. Women still constitute a minority today but there is an increasing number of female high-skilled workers in the manufacturing sector (UNESCO, 2017). Gaps still exist because manufacturing continues to be perceived as a male-dominated sector, meaning women still endure gender bias and gender disparity in $21^{\text {st }}$-century employment. For instance, women get relatively little attention in manufacturing sector; as Cooray (2011) argued that the "economists have in general paid little attention to female employment and training" (p.7). In the training of women,- - the characteristics of the technical and training fields are biased to men, who profoundly dominate the system; for instances, "the labour market presents an ambivalent pictures; discrimination against women still exists, for example in earnings and career option (Kraus, 2006, p.418). Domenico and Jones (2006) describe the challenges faced by women in male-dominated occupations; where "common barriers faced by women included sex-typing of occupations and sex discrimination" (p.2). Caha and Turgunali (2016) discuss this further and highlight three general obstacles faced by women in the engineering field: culture, lack of job satisfaction and work-family conflicts (Çaha \& Turgunali, 2016). Additionally, regional and national factors also contribute to the perception of women in male-dominated occupations. Jaggi, Bahl and Suri (2016) explain that there are different numbers of female employment in manufacturing sector such as "in countries like Sri Lanka and Vietnam, there are more women in the manufacturing industry than man", meanwhile in "South India has a much higher participation of women in the unorganized manufacturing sector than North India" (p.202). In global context, women make up the majority of students in academic institutions (Bilton, 2018) but are far less involved in manufacturing courses and the manufacturing sector (where $16.66 \%$ of female employment in manufacturing industry) (International Labour Organization, 2020).

\subsection{LITERATURE REVIEW}

The manufacturing sector will be heavily impacted by Industry 4.0 technology. One notable impact of this is that new technology promotes a clean, safe and high-tech environment in stark contrast to the nineteenth-century factory floors, which were generally "dirty, rough and noisy"(Annunziata, 2016, p.7). There are nine pillars of technology within Industry 4.0, those being cybersecurity, big data, augmented reality (AR), simulation, robotics, horizontal and vertical system integration, additive manufacturing, internet of things, and cloud computing (Laudante, 2017). These technologies enhance the manufacturing process; they increase flexibility, shorten time to market and maintain high quality and productivity (Zhong, Xu, Klotz \& Newman, 2017).

Based on the literature surrounding Industry 4.0, the new manufacturing environment offers more occupational opportunities for women, such as data scientist, analyst, programmer and software engineer - these positions centre on cognitive abilities instead of physical ones. Despite this, several studies have shown low participation levels among women in the manufacturing sector. In 2017, women made up only 5\% of engineers in Japan; 10\% in the Republic of Korea; 19\% in Canada, Germany and the US; and 22\% in Finland (UNESCO, 2017). This gender disparity was still evident in 2019-women made up only $8.8 \%$ of engineers in England and just $3.2 \%$ in Scotland (The Engineering and Technology Board, 2019, p.5).In the US, women remain underrepresented in the science and engineering fields, making up only $29 \%$ of the workers. According to the Board of Engineers Malaysia (BEM), of the female graduate engineers in the country-just $26 \%$ of total engineering graduates — only $6 \%$ have become professional engineers (The Star Online, 2019). Meanwhile, according to the NGCP resource, only $29 \%$ of those in the science and manufacturing sector are women (National Girls Collaborative Project, 2017). Women have yet to balance out the manufacturing sector despite the technological advancements, and there is a significant research gap on persuading women to be part of the new industrial revolution.

There is serious inequality found in the gender gap. According to the World Economic Forum (2017), there are substantial differences in economic representation in Malaysia. The labour participation rates among women and men there are 52.8 and $81.1 \%$, respectively. The ratio between women and men, respectively, in the professional and technical workforce is $44.4: 55.6 \%$. Notably, evidence indicates that the gender gap and low female participation in the manufacturing industry exists due to several factors, including the low number of female students in academic STEM programs, leadership biases, work-life balance and perceptions that men and women should hold different types of occupations (Mainiero \& Sullivan, 2016; Maji, 2019, p.68). However, it appears as though the arrival of Industry 4.0 technology to the manufacturing sector may reduce these disparities. This technology reduces the necessity of physical strength and instead necessitates cognitive ability and digital fluency; this change could enable women to participate as high-skilled workers in the Industry 4.0 manufacturing sector. Rapid technological advances and the convergence of physical and digital manufacturing are changing the way manufacturers operate and raising the bar for employee skillsets (Giffi, Huelsman, Rodriguez \& McClelland, 2017, p. 4). Hence, the onset of Industry 4.0 technology could reduce gender disparity and enable more women to work in the manufacturing sector. In the Republic of Korea, for instance, the Women in Engineering (WIE) campaign works to improve women's cognitive awareness and encourage them to become highly skilled workers (Youn \& Choi, 2015). This is in line with Sustainable Development Goal 5, "achieve gender equality and empower all women and girls" (United Nations, 2018, p. 8). Also, the World Economic Forum suggests "if current industry gender gap trends persist and labour market transformation towards new and emerging roles in computer, technology and engineering-related fields continues to outpace the rate at which women are currently entering those types of jobs, women are at risk of losing out on tomorrow's best job opportunities while aggravating hiring processes for companies due to a restricted applicant pool and reducing the diversity dividend within the company" (World Economic Forum, 2018, p. 6).

With the arrival of Industry 4.0,the digital industrial revolution- may promotes advanced factory floors that heavily contrast common perceptions - can attract more women to technology and engineering (Annunziata, 2016).. Realistically, however, Industry 4.0 is seen as an uncertain and unstable environment (Shamim, Cang, $\mathrm{Yu} \& \mathrm{Li}, 2016$ ). There are no precise competency requirements for the field (Prifti et al., 2017) and there is low acceptance and readiness among manufacturers (within a Czech Republic context) (Basl, 2017). Additionally, the gender gap has shown few signs of slowing down in the Industry 4.0 manufacturing sector. According to a recent SWOT analysis of women in the manufacturing sector conducted by Jaggi, Bahl \& Suri (2016), "women have prove(n) their mettle, but their presence in manufacturing sector seems to be negligent or on decline" (p. 202). Furthermore, their research discovered thirteen challenges faced by women in the Indian manufacturing environment: gender discrimination; women upbringing; not supportive parental roles; lack of technical skills; domestic and professional exploitation; pay discrimination; gender isolation; physical work expectations; fewer role models; negative growth factor; workplace flexibility; night shifts; and sexual harassment in the workplace (Jaggi, Bahl \& Suri, 2016, pp. 203-208). Considering the existing issues and challenges of women employment in the manufacturing sector, this study aims to explore 
the strengths, weaknesses, opportunities and threats of women employment in the Industry 4.0 manufacturing sector. The research question is thus, simply, as follows: what are the strengths, weaknesses, opportunities and threats of female employment in the Industry 4.0 manufacturing sector?

\subsection{METHODOLOGY}

The extensive literature on women employment in the Industry 4.0 manufacturing sector is reviewed and studied. The identification process of literature reviewed is adapted from Thomas et al., (2014) research work. Thomas et al., (2014) reviewed article based on three stages; a) literature search b) inclusion and exclusion criteria and c) systematic review of literature using the SWOT Framework. The SWOT framework and procedure is made in reference to the SWOT-Matrix framework conducted by Skinner et al. (2012); which emphasizes the positive and negative views of women employment as well as the internal and external factors that influence women employment in the Industry 4.0 manufacturing sector. In literature search (first stage), a wide-ranging online search was conducted in searching literature of women employment in the manufacturing sector of Industry 4.0. There are numerous grey articles identified discussing about women employment in the Industry 4.0 manufacturing sector but few in scientific journals. Several scientific journals database is searched such as European Journal of Women's Studies, Women's Studies International Forum, Journal of International Women's Studies, and Journal of Women and Minorities in Science and Engineering. Following that, the main inclusion criteria (second stage) for the selection of reviewed literature includes the scientific journals (the published empirical or conceptual studies) and grey literature that mentioned women employment either in traditional or Industry 4.0 manufacturing sector. Grey literature are also included in this SWOT analysis as it significantly important in literature search (Paez, 2017); where grey literature provides the insight view of women employment in the Industry 4.0 manufacturing sector from social context perspective instead of academic's perspective.

The third stage is, the systematic review of literature using the SWOT framework. The pattern codes are categorized based on similar data that is obtained from literature reviewed.

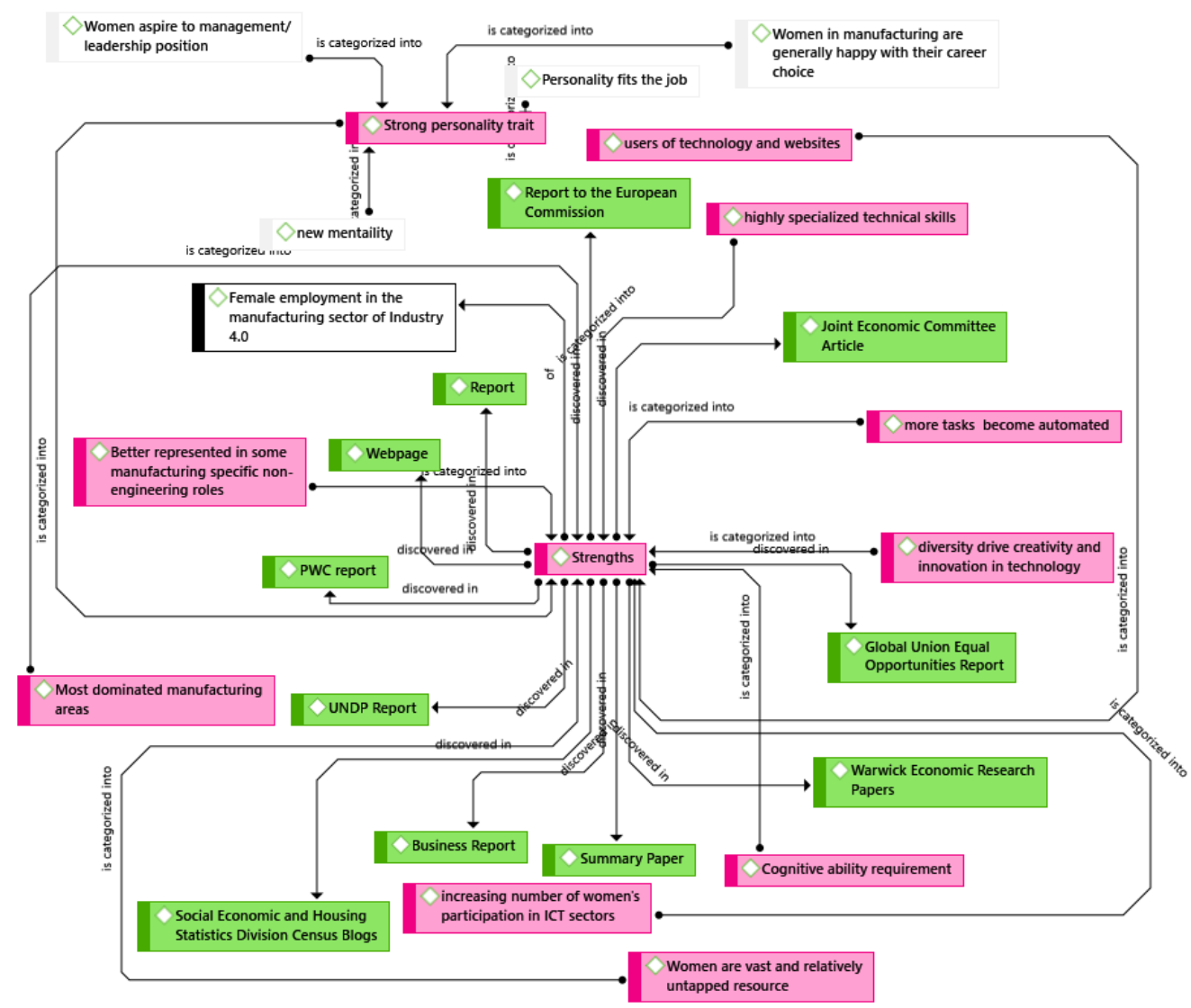

Figure 1 A SWOT Analysis in the ATLAS ti. Network view

Based on Figure 1, the identified strength and source of publication is summarized in Figure 1. The coding template for this study was developed with reference to the research question, which underpins the theoretical concepts of social role theory by Eagly and Wood (2016). The coding process employs the noticing-collecting-thinking (NCT) model (Friese, 2014); where open code and in-vivo code were used in the first cycle; and pattern code in second cycle of coding process. Data analysis was later conducted using a thematic analysis by Braun and Clarke (2006). 


\subsection{RESULTS}

The SWOT analysis is illustrated in Figure 2. Strength and opportunity are indicative of positive views of women employment in the Industry 4.0 manufacturing sector, while weakness and threat are indicative of negative views. '

\section{Strengths}

Throughout the $19^{\text {th }}$ and $20^{\text {th }}$ centuries, production floors were generally described as 'dangerous, dirty and dull', which is not seen as appropriate for women (Annunziata, 2016); physical ability was also a primary concern (Gleeson, 1996). The arrival of Industry 4.0 technology in the $21^{\text {st }}$ century, however, has introduced 'the cleanliness of production, hi-tech equipment and simplified production layout'. Technological advancement may minimise physical work requirements (Joint Economic Committee, 2013) — as more tasks are automated, physical abilities no longer need to constitute major concerns (Annunziata, 2016). Women with academic backgrounds in STEM are now valuable, as modern tasks require greater cognitive abilities and high-skilled competencies (Aulbur, CJ \& Bigghe, 2016; Fleury, Gregory \& Bennett, 2007). Still, strong personality traits can be crucial for women working in the manufacturing sector, which is largely dominated by men. strong personality trait would enable women to work together with men; this diversity could drive technological creativity and innovation, especially in the manufacturing sector (Rübsamen-waigmann et al., n.d.).

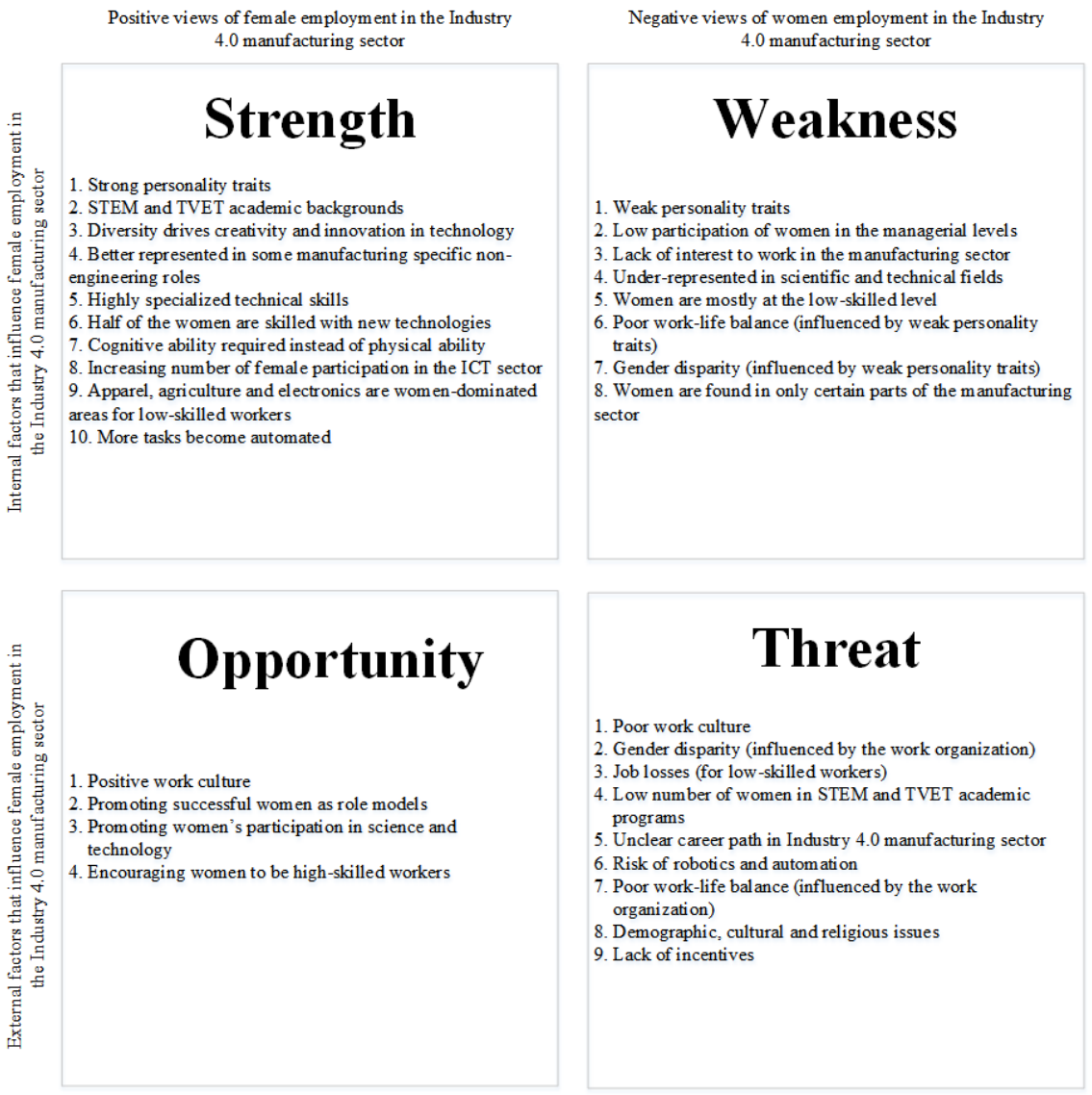

Figure 2 SWOT analysis of female employment in the Industry 4.0 manufacturing sector.

Evidence shows that women are often found in manufacturing-specific, non-engineering roles, such as industrial maintenance technician(University of Strathclyde, 2015). However, in Industry 4.0, women must perform tasks related to industrial automation. These technological tasks require substantial theoretical knowledge and a solid background in STEM. STEM education can act as a foundation for women to pursue a career in the manufacturing sector. Additionally, TVET skills are highly desired for technical tasks linked to robotics and automation. Ras, Wild, Stahl and Baudet (2017) highlight that workers must be able to integrate knowledge into practice. New positions, such as machinist, technologist and robotics engineer, have arisen to perform the new cognitive tasks demanded in the realm of Industry 4.0 manufacturing. Another strength of women employment is that women are illustrated as a vast and relatively untapped resource (Holden \& Morden, 2017). They are able to fill the talent gap not only at the high-skilled level but at the low-skilled level as well. Currently, women are mostly employed as low-skilled workers in the apparel, textile, agriculture and electronics sectors (Business for Social Responsibility, 2017), which are not yet heavily affected by advancing technologies - the work requires human skill and creativity that cannot yet be replaced by a robot. However, progressive research in robotics and automation poses a future risk of unemployment 
among low-skilled workers; this risk could be overcome by equipping women with technology-assisted occupations on the manufacturing floor (Hirsch-Kreinsen, 2016).

\section{Weaknesses}

The biggest weakness discovered of women employment in the Industry 4.0 manufacturing sector is a weak personality trait. While the workplace is fully equipped with new technologies, women with weak personality traits lack confidence, feel insecure (Lambert, 2017), fear venturing in the male-dominated occupation sector (Keller, 2017), negative perception of manufacturing world (Holden \& Morden, 2017) or may not feel suited for work in the manufacturing sector. The rationale behind this is that the manufacturing sector is a maledominated sector - a strong personality is required to work well with men on the manufacturing floor (Gleeson, 1996). Weak personality traits may worsen an already difficult scenario (one with high levels of gender bias and gender disparity), as there are few women at the managerial level (Holden \& Morden, 2017) or, more generally, in the scientific and technical field (Global Union, n.d.). Women with no background in STEM or TVET tend to work in the manufacturing sector as low-skilled workers, meaning they are exposed to a high risk of unemployment due to technological advancement $(\mathrm{Ng}, 2017)$. Additionally, poor work-life balance (University of Strathclyde, 2015) and lack of incentive (Lambert, 2017) contributes to the low participation of women in the manufacturing sector in scenarios both with and without Industry 4.0 technology. As a result, women tend to leave the manufacturing sector as they lost interest and this scenario contribute to low number of women employment in the Industry 4.0 manufacturing sector.

\section{Opportunity}

Positive organisational work cultures can encourage women to stay in the Industry 4.0 manufacturing sector. Organisations that provide training, offer incentives, provide technological access and offer flexible work-life arrangements without being influenced by gender-based biases encourage women to stay in the manufacturing sector (Lambert, 2017; United Nations Industrial Development Organization, 1997; World Economic Forum, 2016). Additionally, promoting successful women in the sector as role models via mentoring programs and showcasing these role models to younger women could increase women's motivation to stay in the field (Joint Economic Committee, 2013; Lambert, 2017). As women are the minority, a role model could provide some intrinsic motivation to the younger generations. Women are also encouraged to enroll in science, technology and technical fields, such as STEM and TVET, so that they leave school with high-skill competencies, which is vital in the Industry 4.0 manufacturing sector (Holden \& Morden, 2017).

\section{Threat}

Women sometimes leave the manufacturing sector due to waning interest in the field's work opportunities (United Nations Industrial Development Organization, 1997). One of the biggest threats is a poor work culture in the organisations. Women often feel that companies do not support their efforts (Holden \& Morden, 2017). Some are forced to move to non-technical roles at their employer's request. Many lack occupational flexibility (Global Union, n.d.), have less access to technology, services and productive assets, and are denied secure and well-paying jobs in (United Nations Industrial Development Organization, 2019). Gender bias among the managerial class is also a problem - there is often a promotion bias favouring men (Holden \& Morden, 2017). There are often assumptions made about women's skills and capabilities, employer preferences based on gender stereotypes and direct instances of unlawful discrimination (University of Strathclyde, 2015).

Other threats discovered in the SWOT analysis are demographic, cultural and religious in nature. The percentage of female employees in the manufacturing sector is higher in high-income countries than in low-income countries (UNESCO, 2017). Additionally, women from high-income countries are mostly at the professional level (engineers) compared to women from middle- and low-income countries. However, women still constitute the minority regardless of demographic and development factors (UNESCO, 2017; Varma, 2018). Additionally, women employment is sometimes strictly restricted in specific regions that are heavily influenced by cultural and religious factors, meaning women are not allowed in male-dominated sectors (Nafchi \& Mohelská, 2018).

Since women are the minority, the scenario only grows worse when women with low-skill jobs could potentially be replaced by robotics and automation. There is time, however-since Industry 4.0 is a relatively new trend, most companies are still implementing the new technology. Women interested in the manufacturing sector are encouraged to continue learning and developing creative and interpersonal skills to face unclear career paths in the Industry 4.0 manufacturing sector (Global Union, n.d.).

\subsection{DISCUSSION}

According to the SWOT analysis, two themes significantly influence the strengths, weaknesses, opportunities and threats of women employment in the Industry 4.0 manufacturing sector. The first theme, the internal factor of women employment, looks at women as human beings. The second theme is the external factor of women employment such as organisational, demographic, cultural and religious issues, as well as technology. Both themes were reviewed and clustered into positive and negative views obtained from secondary data and a literature review to discern the overall findings. Evidence appears to show that the weaknesses and threats could be outweighed by the strengths and opportunities offered by the Industry 4.0 technology. 


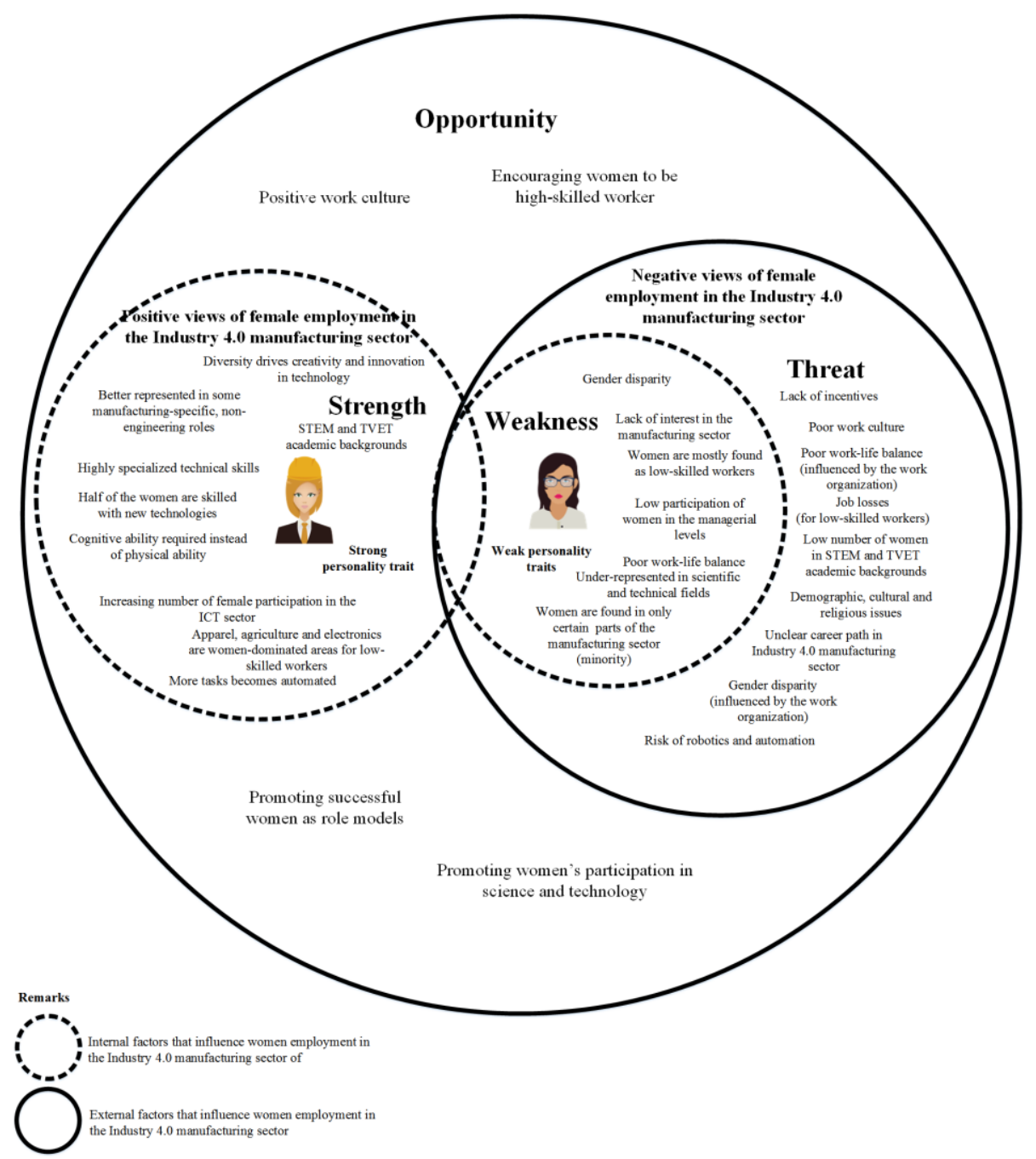

Figure 3 The Strength, Weakness, Threat and Opportunity (SWOT) in reference to external and internal factors

Figure 3 illustrates the strength, weakness, threat and opportunity in reference to the external and internal factors that influence women employment in the Industry 4.0 manufacturing sector. The non-dashed line in Figure 3 refers to the external factors (which indicates threat and opportunity) that influence women employment in the Industry 4.0 manufacturing sector. Meanwhile, the dashed line refers to the internal factors (which indicates strength and weakness) that influence women employment in the Industry 4.0 manufacturing sector. The weakness is a subset of threat; as the threat could become a weakness if no further action taken to overcome the issue and challenges occurred from the Industry 4.0 manufacturing working environment. Also, the women's potential to work in the Industry 4.0 manufacturing sector is not achieved if there are weakness and threat in the manufacturing working environment; which illustrated in Figure 3, the strength is overlapped by the weakness and threat. However, taking the opportunities behind every challenge offered by the Industry 4.0, women's potential to work in the Industry 4.0 manufacturing sector could be achieved if the work organization provides a positive working culture. Therefore, the weaknesses of and threats posed by women employed in the manufacturing sector could be outweighed by the strengths of and opportunities provided by Industry 4.0 .

Harland (1892) described women as human beings. Over the past several centuries, women have been described as emotional, illogical and purely reliant upon 'woman's intuition'. Men, in contrast, have been viewed as strong, aggressive, ambitious and capable (Marriner, 1974). In feminism research, Duncan (2010) further elaborated the relationship between women and feminism. She found that women who are feminist are associated with such labels as outspoken, independent, organised, committed and intelligent (p. 502). Regardless these perception of outspoken, independent, organised, committed and intelligent, women with weak personalities, however, may not be suitable to work in the male-dominated manufacturing sector (Domenico \& Jones, 2006). Even with strong cognitive abilities or relevant academic backgrounds (STEM or TVET), weak personality traits in women such as shy and introvert may be unsustainable in a manufacturing environment, be it with or without Industry 4.0 technology. Additionally, since gender bias and sexism could worsen for women with weak personalities, they may end up developing a negative perception of the sector. In comparison to women with stronger personality traits; they tend to be happier-and more successful, regardless of academic experience-working alongside men at a manufacturing company, be it with or without Industry 4.0 technology. Women without strong personalities often fail to survive in the male-dominated field and tend to lose interest to work over time. Therefore, promoting successful women as role models in the manufacturing sector could be a great effort to encourage a positive presence (Holden \& Morden, 2017). 
Another weakness discovered in this study is that, since women are a minority in the field, they tend to only be found in specific manufacturing sectors, such as textile, apparel, agriculture and electronics. Women dominate the textile and apparel sector, but as lowskilled workers. While apparel and textiles are set to constitute one of the least affected manufacturing sectors by Industry 4.0 , there are still efforts to advance robotics and automation in the field, meaning their jobs are at risk. Women are also a minority in scientific and technical fields. This is due to the low number of women in STEM and TVET academic programs. The lack of a clear career path in the manufacturing sector is one of the reasons behind this low number. Promoting greater participation among women in science and technology, through such means as changing the perception of the field, would attract more women to the manufacturing sector (Holden \& Morden, 2017). Furthermore, low participation at the managerial level is tied to gender bias and gender disparity in the workplace, which could continue to cause women to lose interest in the field. Poor work-life balance also contributes to women's poor perception of the manufacturing sector.

Therefore, a strong personality trait is suggested for women to work in the Industry 4.0 manufacturing sector. Women offer a lot of untapped potential for manufacturers (Holden \& Morden, 2017) and are commonly represented in some manufacturing-specific, nonengineering role (University of Strathclyde, 2015). There have been several successful women in the mechanical engineering field (Hoh, 2007). Successful women serving as role models could encourage the younger generations to work in the manufacturing sector and fight through the barriers and challenges they face there. The new trends of Industry 4.0 are shifting the manufacturing emphasis away from physical ability and to cognitive ability. Two themes are evident. Regarding internal factors of SWOT analysis, recognising the humanity of women leads to the realisation that strong personality traits could enable women to endure hardships and stay in the manufacturing sector. Regarding external factors of SWOT analysis, positive working cultures in professional manufacturing organisations would allow for a more gender-balanced workplace and attract women to the field. Both of these themes demonstrate how women could eventually play a central role in the Industry 4.0 manufacturing sector

\subsection{CONCLUSION}

This study aims to explore the strength, weakness, opportunity and threat of women employment in the Industry 4.0 manufacturing sector by conducting a SWOT analysis in the reviewed literature. Based on the SWOT analysis, the strength, weakness, opportunity and strength of women in the Industry 4.0 manufacturing sector were identified. The findings discover that the main reason of low participation of women employment in the Industry 4.0 manufacturing sector is greatly influenced by several factors such as weak personality traits, gender disparity and lack of interest to work in the manufacturing sector. Therefore, the study suggests a self-reflection for women to identify their own strength and weakness in order to work in the Industry 4.0 manufacturing sector as there are opportunities behind every challenges offered by the Industry 4.0.

Also, the finding suggests women are encouraged to build up strong personality traits as they can well manage work-life balance, easy when dealing with such threats (gender bias) from the workplace and practices leadership in the manufacturing working environment. Additionally, women are encouraged to enroll in STEM or TVET programs to develop the necessary professional foundations. Numerous abilities and bases of knowledge-including programming, coding, app development, system integration, information technology, computer science and Mathematics - contribute to effectively working on machine learning development. Such development is essential to transition to fully automated production. Women with these necessary skills, abilities, and bases of knowledge could thrive as high-skilled workers in the Industry 4.0 environment. Besides, a role model of a successful women in the Industry 4.0 manufacturing sector could be used as an exemplary to encourage women to work in the Industry 4.0 manufacturing sector.

Despite the fact that women are the minority in manufacturing sector and at the managerial level as well as under-represented in scientific and technical areas, the high-technology that is more demanding on cognitive abilities, less physical job requirement, positive working environment and free-gender bias in the Industry 4.0 manufacturing sector may encourage women to participate in the Industry 4.0 manufacturing sector. However, the findings of this study are limited to the secondary data and worldwide issues oriented. Therefore, the finding suggests an empirical study to be conducted to explore the women employment in the Industry 4.0 manufacturing sector in a regional context.

\subsection{LIMITATION AND RECOMMENDATION}

The main limitation of this study is the secondary data that was used to conduct the SWOT analysis. The findings may not be sufficiently credible, as some of it was obtained from grey literature, such as websites, news articles and reports. Additionally, the findings on women employment are in a global context. Future research should be done in a regional context so that a more precise understanding of women employment in the Industry 4.0 manufacturing sector can be uncovered.

Source of Funding: Self-funded

Conflict of Interest: NIL

Ethical Clearance: This research does not require any ethical clearance

\section{References}

Annunziata, M. (2016). Engineering the future: The Socioeconomic case for gender equality engineering the future: The socioeconomic case for gender equality. Aulbur, W., CJ, A., \& Bigghe, R. (2016). Skill Development for Industry 4.O. Roland Berger, BRICS Skill Development Working Group, India Section.

Basl, J. (2017). Pilot Study of Readiness of Czech Companies to Implement the Principles of Industry 4.0. Management and Production Engineering Review, 8(2), 6. Berg, M. (1991). Women's work and the Industrial Revolution. ReFresh, 12, 1-4.

Bilton, I. (2018, February 9). Women are outnumbering men at a record high in universities worldwide. Independant News for International Students, 1-2. Retrieved from https://www.studyinternational.com/news/record-high-numbers-women-outnumbering-men-university-globally 
Braun, V., \& Clarke, V. (2006). Using Thematic Analysis in Psychology. Qualitative Research in Psychology, 3(2), 77-101.

Business for Social Responsability International Center for Research on Women. (2017). Empowering Female Workers in the Apparel Industry. Retrieved June 18, 2020 from https://www.bsr.org/reports/BSR_Empowering_Female_Workers_in_the_Apparel_Industry.pdf.

Çaha, H., \& Turgunali, J. (2016). Women Engineering in Turkey: Case of Istanbul. Procedia Economics and Finance, 38(16), 60-69.

Cooray, A. (2011). The role of the government in work-family conflict. The Vocational Aspect of Education, 21(63), 163-190.

Deloitte. (2017). Women in manufacturing Stepping up to make an impact that matters Deloitte Development LLC. Retrieved June 18, 2020 fromhttps://www2.deloitte.com/ro/en/pages/consumer-industrial-products/articles/women-in-manufacturing-stepping-up-to-make-an-impact-that-mattersstudy.html

Domenico, D. M., \& Jones, K. H. (2006). Career Aspirations of Women in the 20th Century. Journal of Career and Technical Education, 22(2), 1-7.

Duncan, L. E. (2010). Women's relationship to feminism: Effects of generation and feminist self-labeling. Psychology of Women Quarterly, 34(4), $498-507$.

Eagly, A. H., \& Wood, W. (2016). Social Role Theory of Sex Differences. In The Wiley Blackwell Encyclopedia of Gender and Sexuality Studies. John Wiley \& Sons, USA

Fleury, A., Gregory, M., \& Bennett, D. (2007). The future of manufacturing. Journal of Manufacturing Technology Management, 18(8), 323-325.

Friese, S. (2014). Qualitative Data Analysis with ATLAS ti. (K. Metzler, Ed.) (2nd Editio). SAGE.

Gleeson, P. (1996). Women in "men's" work: An issue of identity. Journal of Vocational Education and Training, 48(3), 261-276.

Global Union. (n.d.). Digitalization from a gender perspective. Retrieved June 18, 2020 from www.socialeurope.eu

Harland, M. (1892). Women as Human Beings. The North American Review, 154(427), 758-760.

Hirsch-Kreinsen, H. (2016). Digitalisation and Low-Skilled Work. WISO DISKURS 19/2016. Bonn.

Hoh, Y. K. (2007). Outstanding women in mechanical engineering. International Journal of Mechanical Engineering Education, 35(3), $198-206$.

Holden, M., \& Morden, M. (2017). Attracting and engaging women in Canadian manufacturing, Canadian Manufacturers \& Exporters, 1-20

International Labour Organization. (2020). Employment in industry, female (\% of female employment ) ( modeled ILO estimate ). Jaggi, S., Bahl, S. K., \& Suri, S. S (2016). Women Vs Men in Manufacturing Sector. International Journal of Management \& Social Sciences, 3(2), 197-213.

Joint Economic Committee United States Congress. (2013). Women in Manufacturing, 1-7

Keller, G. (2017). Women and the future of manufacturing. Retrieved September 22, 2019, from kam.co.ke/women-and-the-future-of-manufacturing/

Kraus, K. (2006). Better educated, but not equal: Women between general education, VET, the labour market and the family in Germany. Journal of Vocational Education and Training, 58(4), 409-422.

Lambert, L. (2017). Women and the 4th Industrial Revolution. Retrieved September 22, 2019, from lcr4.uk/2017/05/22/women-4th-industrial-revolution/

Laudante, E. (2017). Industry 4.0, Innovation and Design. A new approach for ergonomic analysis in manufacturing system. The Design Journal, 20(sup1), S2724S2734.

Mack, P. E. (2001). What difference has feminism made to engineering in the twentieth century? ( and L. S. Angela N. H. Creager, Elizabeth Lunbeck, Catharine R. Stimpson, Ed.), Feminism in twentieth-century science, technology and medicine. Chicago: University of Chicago Press.

Mainiero, L. A., \& Sullivan, S. E. (2016). The Opt-Out Revolt. Davies-Black Publishing.

Marriner, G. L. (1974). The Feminist Revolt: The emergence of the new women in the early twentieth century. Humboldt Journal of Social Relations, 1(2), 127-134.

Nafchi, M. Z., \& Mohelská, H. (2018). Effects of industry 4.0 on the labor markets of Iran and Japan. Economies, 6(3), 1-13.

National Girls Collaborative Project. (2017). Statistics State of Girls and Women in STEM. Retrieved June 18, 2020 from http://www.ngcproject.org/index.cfm

Ng, A. (2017). The Times They Are A-Changin': Technology, Employment, and the Malaysian Economy (No. Discussion Paper 1/17). Khazanah Research Institute. Kuala Lumpur.

Paez, A. (2017). Gray literature: An important resource in systematic reviews. Journal of Evidence-Based Medicine, 10(3), 233-240. https://doi.org/10.1111/jebm.12266

Prifti, L., Knigge, M., Kienegger, H., \& Kremar, H. (2017). A Competency Model for "Industrie 4.0" Employees. In 13th International Conference on Wirtschaftsinformatik, 46-60

Ras, E., Wild, F., Stahl, C., \& Baudet, A. (2017). Bridging the skills gap of workers in industry 4.0 by human performance augmentation tools - Challenges and roadmap. In ACM International Conference Proceeding Series, Part F1285, 428-432. https://doi.org/10.1145/3056540.3076192

Rübsamen-waigmann, H., Sohlberg, R., Rees, T., Berry, O., Bismuth, P., Antona, R. D., Winslow, D. (n.d.). Women In Industrial Research : A Wake Up Call For European Industry. European Commission Directorate-General for http://ec.europa.eu/research/swafs/pdf/pub_gender_equality/wir_final.pdf\#view=fit\&pagemode=none

Shamim, S., Cang, S., Yu, H., \& Li, Y. (2016). Management Approaches for Industry 4.0. In Evolutionary Computation (CEC), 2016 IEEE Congress, $5309-5316$.

Skinner, K., Hanning, R. M., Sutherland, C., Edwards-Wheesk, R., \& Tsuji, L. J. S. (2012). Using a SWOT analysis to inform healthy eating and physical activity strategies for a remote first nations community in Canada. American Journal of Health Promotion, 26(6), 159-171.

The Engineering and Technology Board. (2019). Key facts \& figures Highlights from the 2019 update to the Engineering UK report,1-8, Retrieved June 18, 2020 from https://www.engineeringuk.com/media/156198/key-facts-figures-2019-final-20190627.pdf

The STAR Online. (2019, September 20). Empowering women to pursue engineering. The Star Online, 1-5. Retrieved from https://www.thestar.com.my/news/education/2018/08/15/empowering-women-to-pursue-engineering

Thomas, S., Chie, Q. T., Abraham, M., Jalarajan Raj, S., \& Beh, L. S. (2014). A Qualitative Review of Literature on Peer Review of Teaching in Higher Education: An Application of the SWOT Framework. Review of Educational Research, 84(1), 112-159.

Thompson, I. (2004). Sex differences in technical communication: A perspective from social role theory. Journal of Technical Writing and Communication, 34(3), 217-232.

UNESCO. (2017). Women still a minority in engineering and computer science. Retrieved September 21, 2019, from http://www.unesco.org/new/en/mediaservices/single-view/news/women_still_a_minority_in_engineering_and_computer_science/

United Nation. (2018). Transforming Our World: The 2030 Agenda for Sustainable Development. Retrieved September 21, 2019, from https://sustainabledevelopment.un.org/post2015/transformingourworld

United Nations Industrial Development Organization. Sample cases: Women, Industry and Technology (1997), 1-7, Retrieved June 18, 2020 from https://leatherpanel.org/sites/default/files/publications-attachments/women_tech.pdf

United Nations Industrial Development Organization. (2019). Inclusive and Sustainable Industrial Development: The Gender Dimension, 1-70, Retrieved June 18, 2020 from https://www.unido.org/sites/default/files/files/2019-03/UNIDO_ISID_The_Gender_Dimension.pdf

University of Strathclyde. (2015). Making Manufacturing Work for Women, 1-20, Retrieved June 18, 2020 from https://www.closethegap.org.uk/content/resources/Making-Manufacturing-Work-for-Women---Summary-of-research-findings-Close-the-Gap-June2015.pdf

US Department of Defense. (2017). Women's Work. Retrieved September 24, 2019, from https://www.defense.gov/observe/photo-gallery/igphoto/2001719839/ 1/2

Varma, R. (2018). U.S. Science and Engineering Workforce: Underrepresentation of Women and Minorities. American Behavioral Scientist, 62(5), 692-697. https://doi.org/10.1177/0002764218768847

World Economic Forum. (2017). The Global Gender Gap Report. World Economic Forum Report 2017, 1-361, Retrieved June 18, 2020 from http://www3.weforum.org/docs/WEF_GGGR_2017.pdf

World Economic Forum. (2018). Women and Work in the Fourth Industrial Revolution. Retrieved September 21, 2019, from reports. weforum.org/future-of-jobs2016/women-and-work-in-the-fourth-industrial-revolution/

Youn, J.-T., \& Choi, S.-A. (2015). Women Included Engineering Education in Korea. Procedia - Social and Behavioral Sciences, 174, $1678-1683$.

Zhong, R. Y., Xu, X., Klotz, E., \& Newman, S. T. (2017). Intelligent Manufacturing in the Context of Industry 4.0: A Review. Frontiers of Mechanical Engineering, In press, (5), 616-630. 